\title{
CONSUMPTION OF ADVANCED INTERNET SERVICES IN THE ENTERPRISES SECTOR: THE SPREAD OF TELEWORK IN THE METROPOLITAN AREA OF MADRID
}

\author{
José Carlos MACÍA ARCE, Francisco José ARMAS QUINTÁ \\ University of Santiago de Compostela, Spain
}

\begin{abstract}
One of the pillars of the technological revolution that began in the seventies was the development of the Internet. This network has evolved in such a way that it now forms a complex structure that radically changed the social and economic dynamics at the end of century XX. Nowadays, new technologies allow anything from communication and information exchange to the realization of complex financial transactions, all from anywhere in the world and almost instantaneously. In spite of the widespread use of the Internet, there are still territories and inhabitants, mostly emplaced in remote rural areas, who live outside of this technological revolution. By contrast, urban areas enjoy a privileged position in the dissemination of the information society by concentrating most of the telecommunications infrastructure and monopolize the most qualified people. But there are many disparities in terms of diffusion of new technologies and these will transfer, in turn, to the enterprise sector which is the subject of this research. The differences in the use of new technologies and more specifically the use of advanced services on the Internet are related to the sector where the population is employed and its level of training. One of the advanced services offered by the Network is teleworking. Nowadays there are companies that offer their employees the opportunity to develop their professional activities outside their headquarters, using their homes as an alternative or call centers enabled with computers and Internet access. The purpose of this research is the study of the consumption of Internet advanced services by companies in the metropolitan area of Madrid, analyzing the spread of telework in more detail,a potential offered by new technologies and which may modify the current pattern of mobility in the main urban areas because it is from here where big companies are guiding the global economy.
\end{abstract}

Key Words: New technologies, Internet, Advanced Services, Telework, Madrid

\section{Introduction}

The second half of the twentieth century, as a result of the rise of information and communication technology, gave way to the Third Technological Revolution. This brought about a new model of society known as the Information Society or the Network Society (Castells 2000), and superseded the previous industrial stage, hence, some scientists such as Bell (1974), point out to this historical period as the Postindustrial Society. Among the new technologies that emerge in the Third Technological Revolution include computing, telecommunications, microelectronics, optoelectronics and genetic engineering among others. But there the advancements made in computing and telecommunications which were the reason for the Network of networks, the current and popular Internet. This network enabled space-time to be more and more narrow. The territory became speed and the classic concept 
of physical territory, movements and distance, were replaced by transmission and interaction (Ges 1997). These recent technological advancements in communication modes are associated with contemporary globalization (Davies 2004), and cause the formation of a large global network influenced by the flow of communication and economic, political, social and cultural interaction (Short and Kim 1999).

In spite of the great made in the Network of networks in the eighties of the last century, which brought its expansion throughout the world, it was not until the mid-nineties, when the World Wide Web was created, that a great leap in the Internet diffusion process and consequently the Information Society occured. Before this application, the use of Internet was extremely complicated, as it was very difficult to locate and retrieve information. The first browsers and search engines facilitated this process, which led to the creation of a network of global communications with a large amount of information and services that grew every day. At first most Internet users accessed the Net primarily to carry out very simple tasks such as finding information or to communicate with other users. Although the network is becoming more and more popular, currently standing at around two billion users, there are still territories and sectors of the population who live outside of this technological revolution. Today there are many services offered through the Net, by the public or the private sector, ranging from simple hotel bookings or the weekly shopping in a supermarket, to multiple and varied administrative and financial procedures.

Undoubtedly we are witnessing a global opening dominated by communication, as part of a worldwide network that reaches its highest incidence in urban areas. In this global context, the employment situation is closely related to new technologies and the Internet. In economic terms, the information and communications technology eliminate trade barriers and promote the development of international business, leading to the reformulation of corporate strategies (Méndez, 1997). In spatial terms, new technologies cause global cities to concentrate a high percentage of wealth and power, becoming the real economic and political references of modern states (Sassen 2003, Veltz 1999).

With regard to the business world, computer advances change the modus operandi of the companies, information is managed in a more intelligent and more dynamic way and communication is instantaneous and can be done from afar. On the other hand, the net offers companies a new way to promote and sell their products on the market and start buying and selling processes with suppliers and customers. They are certainly very favorable circumstances that significantly change the way to understand business reality (Méndez 1997). However, citizen and company use of the services offered by the Net, especially the most advanced, is not equally distributed in urban areas or rural areas. In the case of urban areas, the presence, use and dissemination of new technologies present contrasts between central cores and their immediate periphery, affecting the citizen's standard of living (Lois et al. 2010).

In this research an analysis of the use of advanced Internet services in the business field in the metropolitan area of Madrid is carried out, with special emphasis on the spread of telework. The study of advanced network services consumption in the enterprise sector, especially the spread of teleworking implies several variables, emphasizing the education of the population, both general and training in new technologies and the spread of these in the business sector. Along with these indicators it is also necessary to take into account other factors such as activity sectors where the population works, population dynamics, ICT infrastructure available, business activity structure and sectors, etc. 


\section{Methodology}

In order to research into the consumption of advanced Internet services by the business sector and the spread of telecommuting in the metropolitan area of Madrid, it was necessary to use various sources from the National Statistics Institute of Spain, the Institute of Statistics of the Community of Madrid, and the National Observatory of Telecommunications and Information Society of Ministry of Industry, Tourism and Commerce of the Government of Spain. To carry this out we used a quantitative methodology based on statistics from public sources, both from national and the Community of Madrid sources.

The study into the use of advanced Internet services and, in particular, the spread of telecommuting in the metropolitan area of Madrid, required the same available data relating to territorial units but the sources presented the data at a different spatial scale. The Statistical Institute of the Community of Madrid offers socio-economic data such as income per capita, the population's level of education, areas of the population's employment, among others, following the regional division NUTS 4 of European Office for Statistics and data on the use of information technology and communications and electronic commerce in enterprises of the Community of Madrid for more than ten employees, with the same territorial basis. However, no data was available for teleworkers with the same level of territorial disaggregation, so data referring to the whole Community of Madrid had to be used. The statistics available on telework in Spain are very scarce and those that are available follow the regional division of the European Office of Statistics, NUTS 2 level. This makes carrying out exhaustive research into the diffusion of telework at the provincial level (NUTS 3), or groups of municipalities (NUTS 4 ) more difficult.

\section{Madrid and its metropolitan area}

The municipality of Madrid has a population of 3,273,049 inhabitants (INE 2010) and the metropolitan area 2,682,320 inhabitants (INE 2010), making a total of 5,955,369 inhabitants. The city and its metropolitan area are structured, following the regional division NUTS 4 of the European Office of Statistics, in five statistics units: Madrid, North Metropolitan, East Metropolitan, Southern Metropolitan and Western Metropolitan (Fig. 1). In the last few years, Madrid has received the influx of thousands of immigrants from other countries. In 2009, the foreign population resident in Madrid and its metropolitan area totaled 808,850 inhabitants $(13.6 \%)$. The Metropolitan North, with 148,640 foreigners of a total population of 312,351 inhabitants, showed the greatest proportion of the foreign population (47.6\%), far above the $5.3 \%$ of the municipality of Madrid (IE 2009). This has made Madrid and its metropolitan area become a multicultural reference in Europe. The advent of these has immigrants changed the social and cultural life of this city and has boosted the economy with the employment of thousands of workers in the construction, industry and service sectors.

The occupied population is employed mainly in the services sector, with values between $81.3 \%$ in the municipality of Madrid, and $67 \%$ in the East Metropolitan. The primary sector has little impact on economic activity, with values always below $1 \%$. Construction and industry maintain a significant presence in the South Metropolitan (30.6\%) and East Metropolitan (32.4\%). Conversely, in the municipality of Madrid there are only $18.2 \%$ of the employed population in the secondary sector (IE 2001). In the urban area of Madrid, outlying cities conform additional spaces and act as sub-centers associated to relatively specialized activities (Méndez 2002). This specialization of cities (shopping and leisure parks, business, industrial, logistical, technological and scientific) causes some spatial segregation which results in significant differences in the distribution of income per capita. Thus, the North Metropolitan (Alcobendas, 


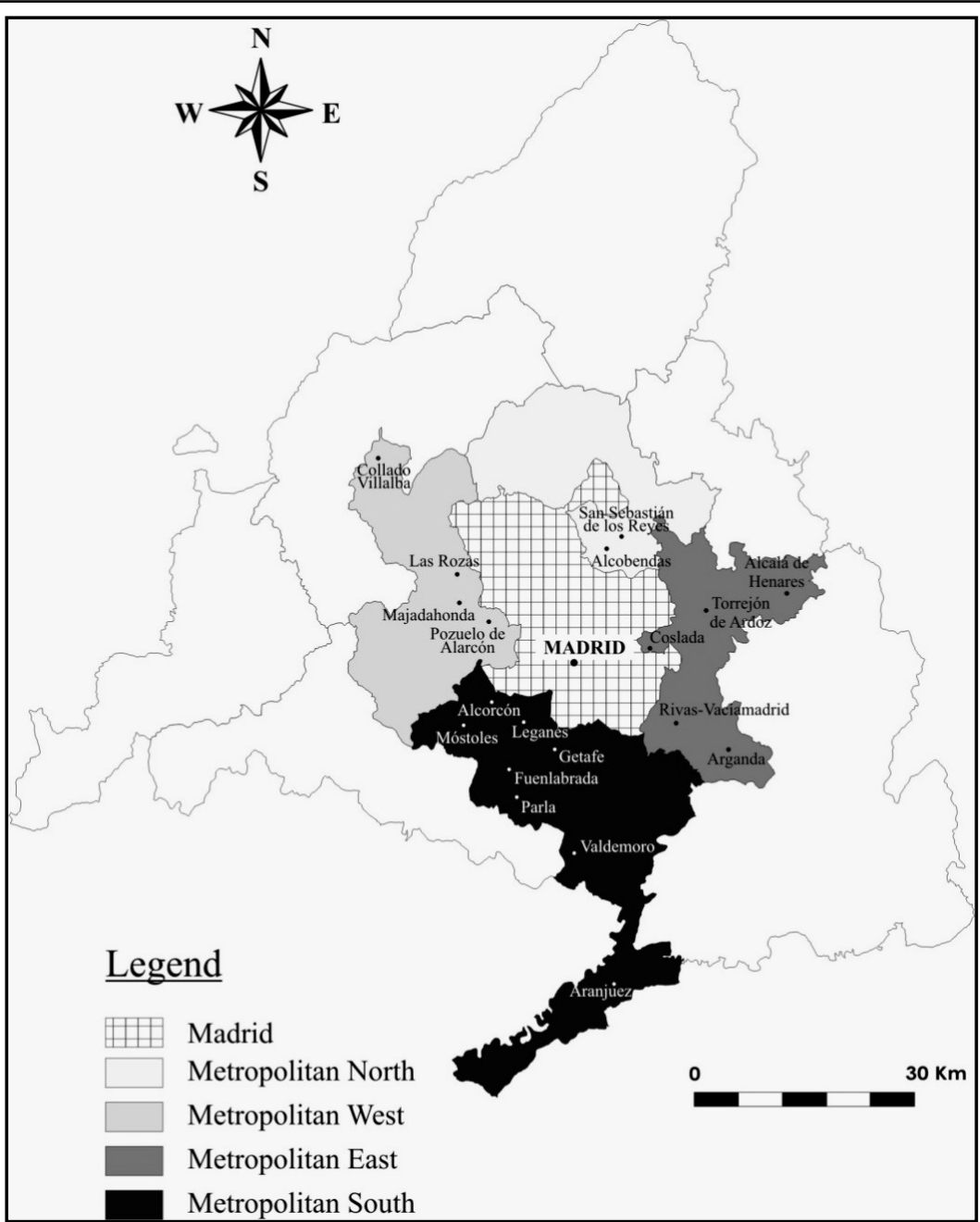

Fig. 1 - NUTS 4 statistical zonification of the Community of Madrid Source: Institute of Statistics of the Community of Madrid, 2011.

San Sebastian de los Reyes, Tres Cantos) registers the best values with $€ 49,965$ per citizen, much higher than the values of the South Metropolitan $(€ 18,544)$ and slightly higher than $€$ 38,539 in the municipality of Madrid (IE, 2010). These differences were also noticed in the use of advanced Internet services by the population (Lois et al. 2011), therefore this issue led us to research what the situation is to this respect in the business field.

\section{The consumption of advanced Internet services in the enterprise sector}

According to the Central Business Directory of the National Institute of Statistics, in Spain there are about three million, three hundred thousand companies of which $95 \%$ are microenterprises (with fewer than ten employees), although these only concentrate $26.7 \%$ of the employee total. 
Large companies (more than 250 employees), represent only $0.2 \%$ of the total, and give work to $26.7 \%$ of the employed population. Of the total companies, six in ten has its headquarters in four regions, Catalonia (18.5\%), Madrid (15.3\%), Andalucía (15.1\%) and Valencia (10.7 \%). In the case of Madrid, the company structure follows the same pattern as at the national level because of the five hundred thousand companies that have their headquarters here, $95 \%$ have fewer than ten employees. The study of the uptake of advanced Internet services in the enterprise sector as well as the spread of teleworking involves analysis of the indicators related to ICT infrastructure and its use by staff and also relate to other socio-economic variables such as the population training, the new technologies degree of use and the activity sectors where people work. This research studies the use of advanced Network companies with 10 or more workers because there are no official statistics for microenterprises.

The spread of new technology equipment in enterprises with 10 or more workers in Madrid is very high because almost all of them have a computer and Internet access through broadband, regardless of activity sector and size. Besides these basic indicators, the use of computers connected to the network by employees, and if companies have their own website and the uses given to them were also considered. From the spatial point of view and regarding the use made of technology workers in these companies, some differences were observed between different regions in the metropolitan area. If in the whole of Madrid half of workers using computers are connected to the Internet, in the metropolitan area, the highest values are recorded in companies located in the north and west metropolitan area, with values above $60 \%$, while the lowest are in the south and east metropolitan areas. These differences were also detected in the size of the company and the activity sector, registering higher values in large companies and in the service sector (Table 1).

Equipment and use of ICT companies in the metropolitan area of Madrid (\%)

\begin{tabular}{|l|r|r|r|r|r|}
\hline & \multicolumn{5}{|c|}{ Statistical Zones } \\
\hline $\begin{array}{l}\text { Enterprises with } \\
\text { Internet }\end{array}$ & Madrid & $\begin{array}{c}\text { Metropolitan } \\
\text { North }\end{array}$ & $\begin{array}{c}\text { Metropolitan } \\
\text { East }\end{array}$ & $\begin{array}{c}\text { Metropolitan } \\
\text { South }\end{array}$ & $\begin{array}{c}\text { Metropolitan } \\
\text { West }\end{array}$ \\
\hline $\begin{array}{l}\text { Workers that use } \\
\text { Internet }\end{array}$ & 52.3 & 97.8 & 98.7 & 98.8 & 99 \\
\hline $\begin{array}{l}\text { Enterprises with } \\
\text { Broadband }\end{array}$ & 99.3 & 90.8 & 41.3 & 48.8 & 62.5 \\
\hline $\begin{array}{l}\text { Enterprises with } \\
\text { Website }\end{array}$ & 88.5 & 87.8 & 99.6 & 99.3 & 89.6 \\
\hline $\begin{array}{l}\text { Enterprises that } \\
\text { bought on Internet }\end{array}$ & 35.9 & 33.7 & 29.5 & 26.2 & 31.5 \\
\hline $\begin{array}{l}\text { Enterprises that } \\
\text { made payments on } \\
\text { line }\end{array}$ & 72 & 65.6 & 65.5 & 60 & 70.6 \\
\hline $\begin{array}{l}\text { Enterprises that } \\
\text { use the Internet } \\
\text { interact with Public } \\
\text { Administrations }\end{array}$ & 90.9 & 91.4 & 86.4 & 88.7 & 90.4 \\
\hline
\end{tabular}

Source: Institute of Statistics of the Community of Madrid, 2006 
(1) Of the total of people

(2) Of the total of enterprises with Internet connection

(3) Of the total of enterprises with Internet connection

(4) Of the total of enterprises with purchases through the Net

(5) Of the total of people in enterprises with Internet connection

Note: Data refers to enterprises in the Community of Madrid for more than 10 workers excluding agriculture, livestock and public administration.

Other basic indicators that were considered were the presence of own website and the main reasons for use, because this tool can serve as a platform for various advanced network services (e-commerce, electronic banking or e-learning) or as a mere fact sheet that serves only to provide information for the presentation of the company and its products. Despite widespread access to Internet using broadband, the case is not the same with the web sites where $15 \%$ of companies use this tool. From a spatial point of view no significant differences were detected, although the presence of corporate websites in Madrid and the North and West Metropolitan is slightly higher than in other regions in the metropolitan area. As for use, almost all companies use their website as a presentation of themselves and their products, but only $20 \%$ of these companies offer electronic commerce in the whole community of Madrid. The same previous pattern is described even when analyzing what happens in the metropolitan area. Companies in the metropolitan north and west have a greater number of enterprises buying and selling on the Net and making payments online, and they also interact more with the public administration, although in this last indicator the differences are less pronounced (Fig. 2). On the other hand, disparities in the size of the companies in the group of large enterprises have also been detected, more than a quarter have never bought online, while only one in ten have done so in the group of small and medium companies.

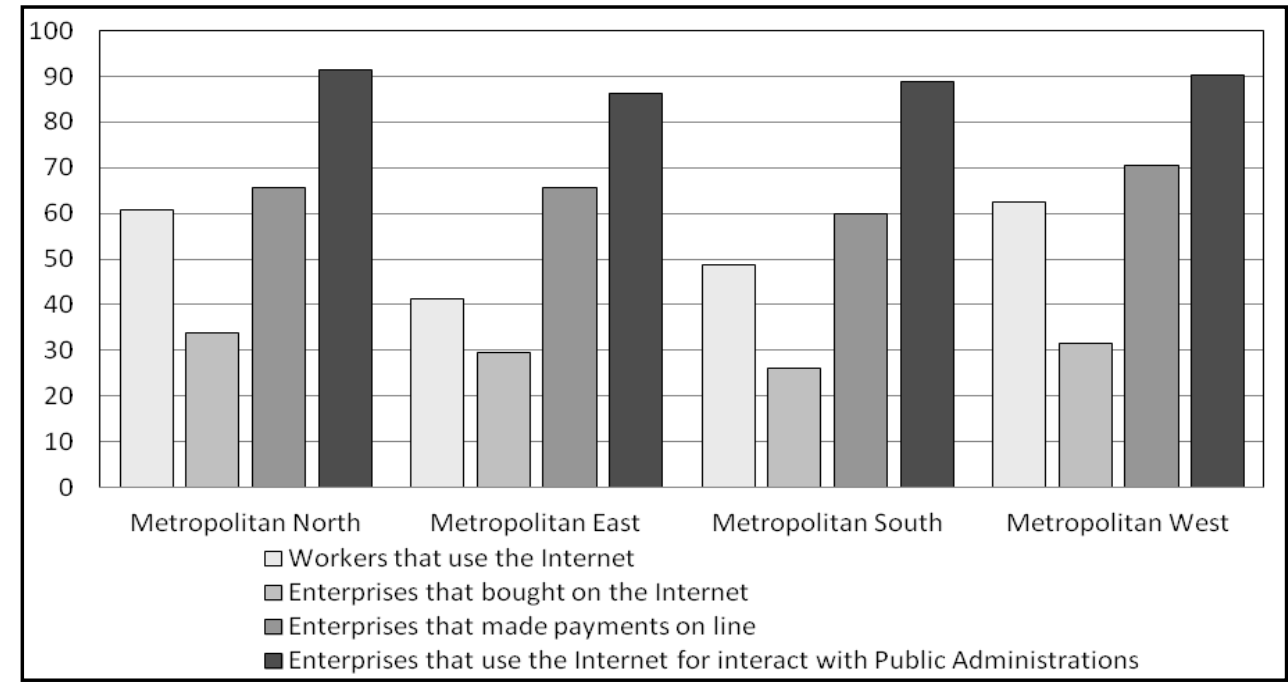

Fig. 2 - Use of ICT in enterprises in the metropolitan area of Madrid Source: Institute of Statistics of the Community of Madrid, 2006.

The spread of electronic commerce was one of the advanced Internet services that have been analyzed in companies in the metropolitan area of Madrid. In this case, we used two indicators; companies that have made Internet sales and the proportion of e-commerce sales over total sales. In addition to electronic commerce, we studied the degree of interaction in business with 
the public administration through the Net. In the metropolitan area of Madrid, in companies established in Madrid and the west and north metropolitan, there is a higher percentage of sales through electronic commerce on the total sales, and it is in these regions where there are a higher proportion of companies that sell on the Net. In this respect there is a difference of more than eight percentage points between the southern and western metropolitan area in the percentage of companies that sell on the Internet (Fig. 3). These differences are found in the use of new technologies and, especially, in the use of advanced network services, which are related to the sector's activity, where the employed population has an equivalent degree of education. In the metropolitan area of Madrid, the south and east region is where more negative data is recorded in regard to the spread of new technologies, both in business and in society, as well as the educational level and income per capita. In these two regions the proportion of the population employed in the service sector is less in detrimental to those employed in construction and industry. The opposite case is recorded in the northern and western metropolitan region where the spread of new technologies is higher in these areas.

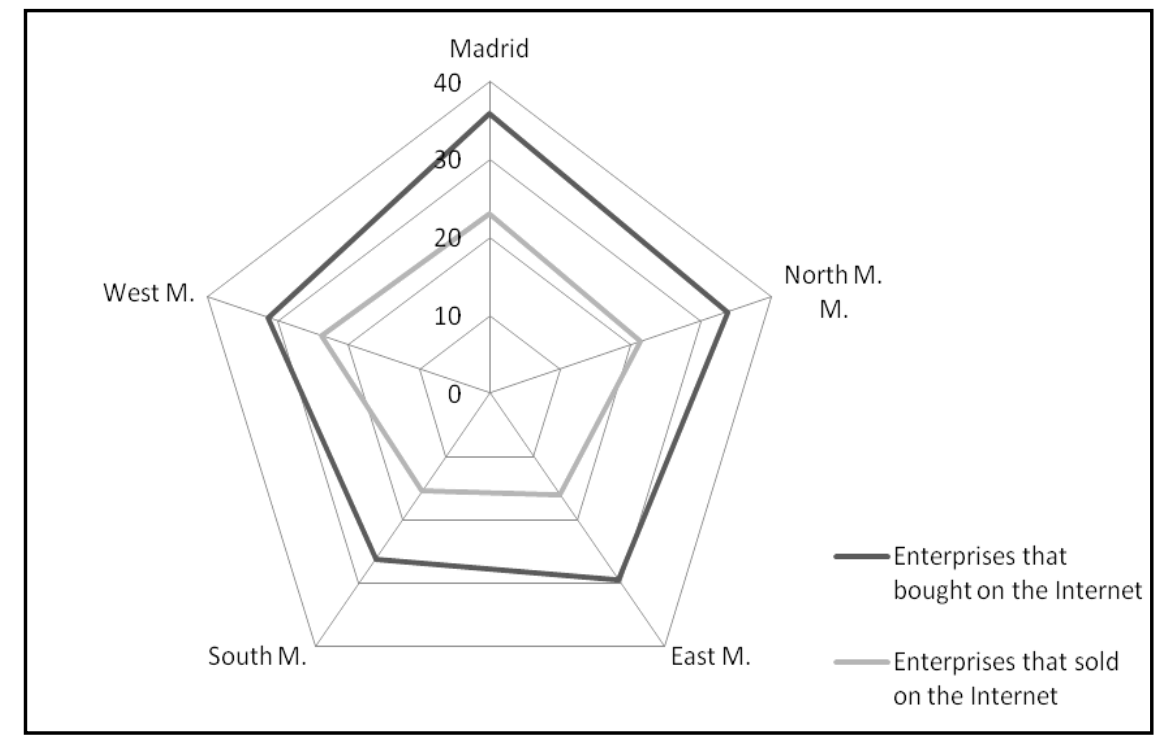

Fig. 3 - The advanced Internet services in the enterprise sector Source: Institute of Statistics of the Community of Madrid, 2011

Note: Data refers to enterprises in the Community of Madrid for more than 10 workers excluding agriculture, livestock and public administration.

\section{Telework and its implementation in the enterprise sector of Madrid}

Teleworking came about as a way to organize such work activity that uses information and communication technology in order to enable distance working, either from a manager's or an employee's home, in commuting, whether it be to airports, hotels or other mobile locations (mobile teleworking) or in call centers or satellite offices designed to reduce the movement of workers (Martinez et al. 2006). According to Grimes (2000) teleworking originated in urban or suburban areas, despite imposition in rural areas, and the characteristics of the activities are, in large, partly associated with processing, management and information recovery. This author defines it as work carried out away from the company location through the use of new 
technology, both to communicate and to exchange information with other employees and customers (Grimes et al. 2003). Simpson et al. (2003) agree with Grimes in relation to the location of telework in the city and they place its origins in the early seventies as an answer to the need to reduce energy consumption, pollution problems and the oil crisis.

Teleworking has a series of benefits among which are: the freedom to work from home, the avoidance of living in large urban areas, increasingly in areas away from city economic and financial centers (Muhammad et al. 2007). Likewise, it expands the process of suburbanization and counter urbanization by improving the welfare of people while avoiding daily commuting to company headquarters. With the spread of telework the household takes on a new role due to the increased number of services derived from the implementation of new technologies. The home ceases to be only a place to relax,rest and spend leisure time and acquires new functions as a workplace, training place, etc. (Cairncross 2001). At the same time, teleworking allows a balance between work and other daily activities enabling greater integration of professional and private life. Moreover, it must be emphasized that, in many cases, telework has removed the concept of "the working day" with one of "continuous availability" (Mattelart 2002).

It seems obvious that teleworking reduces the movement of the employed population to the workplace, reduces congestion caused by excessive traffic (Hjorthol 2008, Safirova 2002), helps to optimize energy consumption (Rhee 2007) and improves citizens' standard of living (Teo et al. 1998). But some of these considerations need to be clarified. For instance, employees covered by the mobile telework modality are distinguished by their great ability to move constantly. On the other hand, teleworking is not always associated with an improvement in citizens' standard of living. Some authors believe that teleworking implies a greater availability of the employee to work, often sacrificing hours destined to leisure (Rhee 2007). Simpson et al. (2003) points out this respect, that teleworking can also cause worker isolation. But this isolation is, after all, subjective because it depends on factors like the type of work that is being done, the worker's attitude to technology, as well as their personal and geographic location. Such deficiencies can be covered, according to the authors, with a number of days in the office or by keeping regular connections with company headquarters.

But the spread of teleworking not only has advantages and benefits, but it also has negative consequences. One is the increase in an individualism culture among the group of teleworkers as a result of poor communication between the company and the teleworkers, and even difficulty involved in separating professional and personal life. Many teleworkers have an urgent need to check email at night and during the weekend, with the fear of not consulting messages that could be relevant for their work in time. It is very important to minimize these problems and try to facilitate open communication between the teleworkers and the company in all matters relating to cooperation in order to take part in joint projects and informal communication (IBM 2005).

Regarding the study of the spread of teleworking in the enterprise sector in Madrid, it is necessary, in addition to specific indicators that refer to telework, to take into account other variables because it is closely related to the type of activity carried out by the company. These include those related to the population's education and the degree of new technologies usage. The statistics related to telework are very scarce and, in the case of Spain, they are at regional level. This makes it impossible to carry out exhaustive research at municipal level or by groups of municipalities (NUTS 4) as has been done in the case of the use of advanced Internet services. 
The spread of telework in Spain is still too limited, although it has undergone significant growth over the past ten years. According to the Institute of National Statistics, in Spain in 2011 only $21.6 \%$ of companies had employees partially working off the company premises and accessing company information and communication technology from other locations. The region that has more companies with teleworkers is Catalonia with $27.4 \%$, followed by Madrid with $27.3 \%$ and the Basque Country with $23.2 \%$. On the other hand, there are communities where telework has less impact, as is the case of Extremadura, the Balearic Islands and La Rioja, where only $15 \%$ of companies have teleworkers. This data is far removed from that achieved by the enterprise sector in equipment and basic uses of the Network. In the case of companies with ten or more workers in Madrid, taking data for the year, $98.5 \%$ had computers, $98.4 \%$ had broadband Internet access, $69 \%$ of companies with Internet had their own website, and $97 \%$ use email. Even in the consumption of some advanced services on the Internet, companies in Madrid registered positive data, where $91 \%$ use the Internet to contact the government, over $70 \%$ make online payments, and $36 \%$ make purchases on the Internet. However, the implementation of teleworking in the companies in the Community of Madrid come in much lower positions despite the advances made in the last five years, rising seven percentage points in 2011 in $27 \%$ of companies with telecommuters.

\section{Concluding thoughts}

The study into the use of advanced Internet services in companies in the urban area of Madrid concluded that there is a direct relationship between the use of information and communication technology, and some socioeconomic indicators such as per capita income, the qualification level of population, and its employment sector. The number of Net users has grown significantly over the last ten years, especially in the Community of Madrid, and likewise the number of services offered by the network, both from the government and the private sector. In the metropolitan area of Madrid, some differences were observed regarding the use of network services by the enterprise sector, that arise from disparities in the level of the population's education, income per capita and industry occupation. The north and west metropolitan registers the highest percentage of Net users, and it is also where companies located in these two regions have the largest number of registered e-commerce sales on total sales, where most companies carry out electronic commerce in relative values, and where a greater number of firms contact, through the network, the public administration, although in the latter the differences are less pronounced. This data is directly linked with income per capita in these regions, which is the highest in the region, as well as the educational level of the population and the proportion of assets in the service sector.

Regarding the spread of telework in the Community of Madrid, this is presented as a new way to offer new technologies for the restructuring of the organizational model and the production process in the enterprise sector in the information society. It is an alternative way to integrate the younger population and the highly skilled into the labor market and to reduce daily journeys with the corresponding energy consumption and environmental impact. It has achieved significant advances in the process of immersion of the enterprise sector into the information society for practically all companies in the community of Madrid, through having an Internet broadband connection, and the consumption of the advanced services Network in recent years. But despite Madrid coming top with the highest proportion of companies with teleworkers at $27 \%$, significant efforts are needed to consolidate this new way of working. In the spread of telework process, new technologies have a crucial role, but they, themselves are not able to carry this out; the companies are the main protagonists in this process. Economic pressures and the competitive environment lead companies to seek solutions to optimize their productivity, reduce costs and outsource some jobs. The enterprise sector in the Community of 
Madrid has all elements to promote the spread of telework, because this region has the infrastructure and the human capital necessary to carry it out.

\section{References}

ARMAS QUINTÁ, F.,J., MACÍA ARCE, J., C. (2011), Teletrabajo y usos racionales del transporte público y privado en el área urbana de Madrid in Urbanismo expansivo, de la utopía a la realidad, Actas del XVIII Congreso de la Asociación de Geógrafos Españoles, Alicante, Asociación de Geógrafos Españoles, Colegio de Geógrafos de España, Universidad de Alicante.

BELL, D. (1974), The coming of Post-Industrial Society, London, Heinemann.

CAIRNCROSS, F. (2001), The death of distance 2.0. How the communications revolution will change our lives, London, Texere.

CASTELLS, M. (2010), Globalisation, networking, urbanization: reflections on the spatial dynamics on the information age, Urban Studies, 47 13, pp. 2737-2745.

CASTELLS, M. (2000), La era de la información: economía, sociedad y cultura. La sociedad red, Madrid, Alianza Editorial.

DAVIES, W., K., D. (2004), Globalization: A Spatial perspectiva in MATTHEWS, J.,A., HERBERT, D.,T. (Ed.), Unifying Geography, Common Heritage, Shared Future, London, Routledge, pp. 192.

GÉS, M. (1997), La cultura telemática y el territorio in La Factoría, 2, http:// www.lafactoriaweb.com

GRIMES, S. (2000), Rural areas in the information society: diminishing distance or increasing learning capacity?, Journal of Rural Studies, 16, 1, pp. 13-21.

GRIMES, S. (2003), The digital economy challenge facing peripheral rural areas, Progress in Human Geography. 27, 2, pp. 174-193.

HJORTHOL, R. (2008), Teleworking: a reduction in travel or just increased flexibility?, The Journal of E-working, 2, pp. 81-94.

IBM (2005), The mobile working experience. A European perspective, New York, IBM Corporation, http://www-1.ibm.com/services/us/imc/pdf/g510-4029-mobile-workingexperience.pdf.

LOIS GONZÁLEZ, R., C., MACÍA ARCE, J., C., ARMAS QUINTÁ, F. J. (2010), ICT inequalities in the Spanish urban system, Journal of Urban and Regional Analysis, 2, 2, pp. 1932.

LOIS GONZÁlEZ, R., C., ARMAS QUINTÁ, Fr., J., MACÍA ARCE, J., C. (2011), Consumption of Advanced Internet Services in urban areas: A case study of Madrid, Book of Abstracts, Urban Transformations, Canterbury Christ Church University, IGU Canterbury Meeting.

MARTÍNEZ SÁNCHEZ, A., PÉREZ PÉREZ, M., DE LUIS CARNICER, P., VELA JIMÉNEZ, M. (2006), Trabajo y flexibilidad: efecto moderador sobre los resultados de la empresa, Cuadernos de Economía y Dirección de la Empresa, 29, pp. 229-262.

MATTELART, A. (2002), Historia de la sociedad de la información, Barcelona, Paidós, $193 \mathrm{p}$.

MÉNDEZ, R. (1997), Geografía económica. La lógica espacial del capitalismo global, Barcelona, Ariel.

MÉNDEZ, R. (2002), La evolución de los mercados de trabajo metropolitanos: realidades y mitos a partir del ejemplo de Madrid, Scripta Nova, VI, 119.

MUHAMMAD, S., OTTENS, H., ETTEMA, D., DE JONG, T. (2007), Telecommuting and residential locational preferences: a case study of the Netherlands, Journal of Housing and the Built Environment, 22, 4, pp. 339-358.

RHEE, H. (2007), Home-based telecommuting and commuting behavior, Journal of 
Urban Economics, 63, pp. 198-216.

SAFIROVA, E. (2002), Telecommuting, traffic congestion, and agglomeration: a general equilibrium model, Journal of Urban Economics, 52, pp. 26-52.

SASSEN, S. (2003), Los espectros de la globalización, Buenos Aires, Fondo de Cultura Económica, $276 \mathrm{p}$.

SHORT, R., KIM, J. (1999), Yeong Hyun. Globalization and the City, Harlow, Essex, Longman.

SIMPSON, Lyn, DAWS, Leonie, PINI, Barbara, WOOD Leanne (2003), Rural Telework: Case Studies from the Australian Outback, New Technology, Work and Employment, 18, 2, pp. 115-126.

TEO, T., LIM, V., WAI, S. (1998), An empirical study of attitudes towards teleworking among information technology (IT) personnel, International Journal of Information Management, 18, 5, pp. 329-343.

VELTZ, P. (1999), Mundialización, Ciudades y Territorios, Barcelona, Ariel.

Initial submission: 21.10 .2011

Revised submission: 14.04 .2012

Final acceptance: 31.05 .2012

Correspondence: University of Santiago de Compostela, AVDA. DAS CIENCIAS, S/N. 15782, Santiago de Compostela, Spain.

E-mail: francisco.armas@usc.es 
